\title{
Oil Crisis in the Niger Delta Region of Nigeria: Genesis and Extent
}

\section{Tombari Bodo, PhD}

Department of Geography and Natural Resource Management, Faculty of Social Science, University of Uyo, Akwa Ibom State, Nigeria

\section{Batombari Gbidum Gimah, PhD Student}

Department of Environmental Adult Education, Faculty of Education, Ignatius Ajuru University of Education, Iwofe, Rivers State, Nigeria

\section{Doi:10.19044/esj.2019.v15n36p141 URL:http://dx.doi.org/10.19044/esj.2019.v15n36p141}

\begin{abstract}
The people of Niger Delta have suffered several years of negligence and marginalism from the exploration of petroleum and distribution of its products by multinational oil companies and the government. This has necessitated attacks from the locals on government forces, oil workers, and oil installation sites as a means of expressing their grievances. The oil crisis in the region has led to the disruption of oil exploration and reduction of revenues accruing to the state from the sales of oil. These crises have led to the multiplication of several criminal vices that has turned the region into a state of disarray. The military and the militants are currently benefiting from the booming business of illegal bunkering, pipeline vandalism, and diversion of refined petroleum products running through the pipes from the refineries. This paper focuses on examining the history of oil exploration, origin, and consequences of the oil crisis in the Niger Delta, and how the government can put an end to this menace.
\end{abstract}

Keywords: Oil Crisis, Niger Delta Region, Exploration, Oil Companies, Petroleum, Militancy

\section{Introduction}

Among the 20 major deltas in the world, the Niger Delta is ranked as one of the largest wetlands, Africa's largest delta, and possibly the richest in the world in terms of oil and gas reserves (Badmus, 2010; Fagbadebo \& Akinola, 2010; Ogbonna \& Ebimobowei, 2012). The oil industry is a blessing to the Nigerian economy and have contributed the lion share to the Gross Domestic Product (GDP) accounting for the bulk of Federal Government revenue and foreign exchange earnings since early 1970 
(Nwoba \& Abah, 2017; Bodo, 2018). The Oil and Gas sector is the mainstay of Nigeria's economy, contributing more than $90 \%$ of Nigeria's foreign exchange earnings and $83 \%$ of its GDP (Ogbeifun, 2014; Nwoba \& Abah, 2017). Between 2000 to 2009, the price of crude oil rose from $\$ 13$ per barrel to a high rate of $\$ 125$ per barrel, thereby increasing the Nigeria's annual budget expenditure between the period under review from $\mathrm{N} 470$ billion to N2.676 trillion (Ogbonna \& Ebimobowei, 2012). Within this same period, the total recurrent expenditure increased as a result of increase in salaries and expansion of government ministries and agencies (Ogbonna \& Ebimobowei, 2012).

Multinational oil companies operating in the Niger Delta region of Nigeria has generated huge revenues for the Federal Government of Nigeria (FGN) through the taxes, royalties, and levies paid for the production and supply of energy running into billions of dollars (USD). It is already a known fact that Nigeria depends on the oil and gas industry for more than $90 \%$ of its export earnings and about $80 \%$ of government revenue (Ibori, 2009). The Shell Petroleum Development Company (SPDC) on their own part, through their operations in the onshore and shallow water, contributed about $\$ 900$ million (N272.72 billion) in taxes and royalties in 2018. On the other hand, the Shell Nigeria Exploration and Production Company (SNEPCo), which operates in the offshore deep water, contributed about $\$ 800$ million (N242.42 billion). In 2018 alone, Nigerian Liquefied Natural Gas (NLNG) paid approximately $\$ 398$ million (N120.61 billion) in income tax to the FGN (SPDC, 2019). Despite these huge returns into the government purse, the people of the Niger Delta still suffer from lack and want with other severe consequences (Akpan, 2014; Bodo, 2018; Bodo, 2019). Ironically, despite this tremendous natural resource endowments, the Niger Delta region houses one of the extreme situations of poverty and underdevelopment (Odalonu \& Eronmhonsele, 2015). Consequently, the region is characterized by low Infrastructural development and an unemployment level of over 85\% (Odalonu \& Eronmhonsele, 2015). For a region that accounts for over $80 \%$ of Nigeria's oil production with over 600 oil fields, 5,284 oil wells, 10 oil and gas export terminals, 275 flow stations, 10 gas plants and massive liquefied natural gas (Ibaba, 2009; Aghedo, 2011 Odalonu \& Eronmhonsele, 2015), basic social amenities are said to very limited, falling below the national average in all measures or indicators of development (Ibaba, 2005; Ejovi, Ebie, \& Akpokighe, 2014; Odalonu \& Eronmhonsele, 2015).

Oil disputes between Cross River State and Akwa Ibom State, Rivers State and Akwa Ibom State, and Rivers State and Bayelsa State over ownership of oil blocks resulted to violence and conflicts between the host communities within the oil blocks in these states (Akpan, 2014). Several 
lives have been lost on the part of the stakeholders (Multinational oil operators, government, host communities) as there had been cases of missing military officers that were assigned on a special assignment in the region; oil company workers had been kidnapped and killed on many occasions; and many oil facilities has been shut down permanently in Ogoniland at the expense of the government (Akinola, 2008; Akinbi, 2012). The host communities in the Niger Delta has the lion share of these losses: the killing of more than 2,500 persons in Odi community in Bayelsa State on the $20^{\text {th }}$ of November, 1999, by the Nigerian military; the killing of four prominent Ogoni leaders by the locals, and the subsequent illegal trial and execution of Ken Saro Wiwa and eight other Ogoni sons by the military government (Osaghe, 1995; Nannen, 1995; Rafiu, 2008).

Thereafter, there were declarations of independent kingdoms by different aggrieved parties and societies, which were presumed to be separate and distinct from Nigeria (Aghalino, 2001). Subsequently the formation of different angry militant groups followed (Akinbi, 2012; Aghalino, 2012). These militant groups used different approaches to draw the attention of the multinational companies and government to their plights. From 2006 to 2009, all hell broke loose in the region and beyond as over 90 billion naira was amassed by these militants through payment of ransom from the kidnapped victims, with other vices like illegal bunkering and vandalism of pipeline that were being perpetrated (Ukelegbe, 2006; Akinbi, 2012; Bodo,2019).

This paper reviews the genesis of oil crisis, the extent of the crisis, and the possible solutions in the Niger Delta region of Nigeria.

\section{The History Of Oil Exploration In Nigeria}

The beginning of colonial rule in Nigeria coincided with the expansion of oil exploration in most countries of the world. There was high demand for oil and other lubricants due to the development of the combustion engine in the 1890's (Udosen, Etok \& George, 2009). At the same time, there was increased need for military ships to protect the island following World War I (Collins, 2018). The British government decided to explore their colonies for oil resources to meet up the demands back home. Nigeria, being one of those colonies, was explored first for bitumen, coal, and finally oil (Udosen et al., 2009). Oil exploration and exploitation in Nigeria is believed to have started far back 1903 with the British Mineral Survey Company (World Bank, 2000; Collins, 2018). Much later, around 1908, the German surveyors of the Nigerian Bitumen Corporation began prospecting for Tar Sand deposit in Araromi in the present Ondo State (Udosen, Etok \& George, 2019; Aniefiok et al.,2013).

By 1914, the British government passed the first mineral oil 
ordinance that was controlled solely by them as they excluded non British subjects from having right of oil exploration in Nigeria (Aniefiok, 2013; Collin, 2018). However, these pioneering efforts ended with the outbreak of the World War I in 1914. After several years later, petroleum exploration began again in 1938, when Shell D'Arcy (a consortium of Iranian Oil Company that later became British Petroleum and Royal Dutch Shell) was granted a sole ownership right over the whole country (Aniefiok et al., 2013; Udosen et al., 2009). Again, the World War II that started between 1939 to1945 terminated the oil exploration activities by Shell D'Arcy. Oil exploration in the Nigeria's Niger Delta resumed in 1946 after World War II with several exploratory wells as the search for oil persisted. After years of continuous search with a reported investment of over $\$ 30$ million spent by SPDC, the first recorded commercial quantity of petroleum was discovered at Oloibiri and Afam oil fields in the Niger Delta in 1956 (Udosen et al., 2009; Bodo, 2019).

There were reports that SPDC was successful in oil discovery in other settlements like Bomu oil field in Ogoniland. However, such findings were only reported at a later date in 1958 (Aniefiok et al., 2013; Bodo, 2019). The giant Bomu oil field was reported as having an estimated ultimate recovery (EUR) of 0.311 billion of barrels (BB) of oil and a total of 0.608 billion of barrels of oil equivalent (BBOE) including gas, making this oil field a massive treasure to the operating company (SPDC) and the Nigerian government (Vassiliou, 2009; Aniefiok, et al., 2013). Mobil Producing (Nigeria) Ltd, a subsidiary of American Socony- Mobil Oil Company, was also at the background working their way into Nigeria. Thus, they obtained license to explore for oil and began operations in Nigeria in 1955 under the name Mobil Exploration Nigeria Incorporated which was later incorporated as Mobil Producing Nigeria on June 16, 1969 (Aniefiok et al., 2013). In 1958, SPDC started oil production and export from the Oloibiri field in Rivers State (presently in Bayelsa State) at the rate of 5,100 barrels per day and about 10,500 barrels the following year (Udosen, et al., 2009).

By 1960, the petroleum sector was beginning to gain weight in transforming the Nigerian economy and the dominant source of revenue (which was agriculture) began to lose relevant, as government was focused on expanding the oil and gas sector (Adomakai \& Sheate, 2004). As a result, the Nigerian government abandoned other sources of revenues (like agriculture, manufacturing, creative arts and entrepreneurship) that was already giving the country recognition overseas (Adomakai \& Shaete, 2004). It was not a surprise that immediately this policy was introduced, other multinational oil and gas companies started coming to Nigeria to do business and make as much profit as possible why the offer lasted. In 
addition, non-British firms were also granted license to explore oil (Aniefiok, et al., 2013; Bodo, 2019). Subsequently, Mobil came in 1955, Texaco Overseas Nigeria Petroleum Company Unlimited in 1961, Amoseas in 1961, Gulf Oil Company in 1961 (now Chevron), Société Africaine des Pétroles (SAFRAP) in 1962 (which later became Elf Nigeria Limited in 1974), Tennessee Nigeria Limited (Tenneco) in 1962, Azienda Generale Italiana Petroli (AGIP) in 1962, ENI in 1964, Philips Oil Company in 1964, and Pan Ocean Oil Corporation in 1972 (Poindexter, et al., 2008; Udosen et al., 2009; Aniefiok, et al., 2013). These multinational oil and gas companies within few years in Nigeria's oil business became richer than some countries in the world today. They grew from small start-up companies to oil giants in the world today. Thus, they recorded remarkable successes in oil and gas exploration and production in both onshore and offshore fields in the Niger Delta (Doyle et al., 2008; Obaje, 2009; Aniefiok et al., 2013). For example, in 1984, Nigerian Agip Oil Company started its operations in Ibocha-Obiafu axis of Ogba-Egbema-Ndoni Local Government Area of Rivers State. Currently, they (AGIP Oil Company) have built the largest gas plant in the entire West Africa in Omoku and have spread almost to the entire Niger Delta region of the South-South. One thing is clear for all to see, oil business in Nigeria is good for the multinational oil and gas companies, as their stations where company machines and staffs resides, have been transformed into little heavens on earth (Bodo, 2019; Bodo \& David, 2018; Bodo,2018).

As oil exploration progressed in Nigeria, the Nigeria Government became aware that they were outsmarted in the oil business and decided to create the Department of Petroleum Resources (DPR) Inspectorate in 1970. Later on, Nigeria joined the Organization of the Petroleum Exporting Countries (OPEC) in 1971 (Aniefiok, et al., 2013). The first national oil company, the Nigerian National Oil Corporation (NNOC), was created in 1971 and it later became the Nigerian National Petroleum Corporation (NNPC) in 1977 (Aniefiok, et al., 2013). The Federal Government of Nigeria went on to take control of the country's petroleum industry by nationalizing BP's holding completely in 1979, and Shell-BP became Shell Petroleum Development Company of Nigeria (SPDC) in the same period (Aniefiok et al., 2013). Also, SPDC was in-charge of producing about 39 per cent of the nation's oil and remains the major producer in the Nigeria's petroleum industry (Obaje, 2019; Bodo, 2019). In January 1979, Nigeria attained its all-time peak in petroleum production at the rate of 2.44 million barrels per day, with millions of dollars going into the government accounts daily from oil sales (Udosen, et al., 2009; Bodo,2019).

The Niger Delta region is truly blessed and it is reported to have 31 giant oil and gas fields. This is with an estimated ultimate recoverable oil of 
more than 500 million barrels that produces in excess of 1 million barrels a day (Obaje, 2009; Pearson, 1970). Vassiliou (2009) reported that 17 of the giant oil and gas production fields are located offshore and some of them include Bomu (which is cited in Kegbara Dere in Gokana in Rivers State), Oso, Ubit, Assan, Meren, Abo, Bonga, Bonga Southwest and Agbami, etc. (Obaje, 2009; Genova,2007).

The Niger Delta oil is not only very important for the survival of the Nigeria state but also to other nations of the world (Asuni, 2009). The hike in oil prices at the gas stations around the world by January, 2006, was a clear indication that the activities of militant groups in the region have affected international oil supplies (Asuni, 2009). By 2008, the cost of oil was $\$ 147$ per barrel, at a time when oil production in the Niger Delta was down by a quarter (Asuni,2009).

\section{Genesis Of The Crisis In The Niger Delta Region Of Nigeria}

Ever since oil was discovered and reported officially in Nigeria in 1956, it has been a source of strife and violence (Vangham, 2011). The crisis in the Niger Delta region did not start today. Even before Nigeria was officially incorporated into the British Empire in 1900, the Niger Delta has a long history of clashes and external commercial activities with the outside world primarily through the palm oil and export of slaves before the British banned the slave trade (Udosen et al., 2009; Francis, Lapin \& Rossiasco, 2011). The Niger Delta people are majorly into agriculture even before the British colonialism. Palm oil from the region was exported in exchange for the importation of manufactured goods. Port Harcourt Port in the Niger Delta supported active trading, importation, and exportation of goods during this period. Yet the major ethnic groups profited above the minor groups within the Niger Delta. Also, the British government during the colonial era failed to address the neglect of the minority ethnic groups and that has persisted even after the Nigerian independence in 1960 (Frederick et al., 2013).

According to history, the Royal Niger Company was in-charge of business in the Niger Delta region (Aniefiok et al., 2013). This company monopolised governance and trade of the region, and they were very hostile within the period of its exploitative practices that resulted in an attack on its headquarters in Akassa by the king of Brass in 1895 (Udosen, Etok \& George, 2009). The Royal Niger Company later sold all its asset and areas of dominance to the British Government in 1900 (Aniefiok et al., 2013). The people in the Niger delta region of Niger Delta (that was later called the Oil Rivers Protectorate, and then incorporated into the Southern Protectorate that was amalgamated in 1914 into a unified Nigeria) had always agitated against the unfair treated meted to them (Udosen et al., 
2009). The people of Niger Delta have always been outspoken against all forms of marginalisation and ill treatments. For as far back as 1929, the women of Aba were provoked by rumours of a new income tax and came into direct and violent confrontation with the police. As a result, more than fifty women were killed in the riots (Bodo \& David, 2018; Francis et al., 2011; ICG,2006).

The ethnic minorities of the Niger Delta began to express their concerns even during the transition to independence in the 1950s; however, the first major episode of militancy in the Niger Delta occurred in February 1966, when Isaac Boro (Ijaw born in Oloibiri), a leader of the Niger Delta Volunteer Force (NDVF), declared the independence of the Niger Delta People's Republic, which consisted of the present day Rivers and Bayelsa States. Thus, he called the multinational oil companies to negotiate directly with his government (Udosen et al., 2009). After Boro's failed attempt in liberating his people, the Niger Delta became increasingly marginalized from the political and economic systems with the progressive degradation of the environment due to unsustainable oil exploitation and impoverishment. This increased the minorities' feelings of frustration against the federal government (Ebeku, 2001; Bodo, 2018; Bodo, 2019; Udosen et al., 2009).

By 1979, the Federal Government of Nigeria (FGN) had established the oil deposits as a national asset ensuring that everywhere oil exploitation is operational, is solely government property and business depriving the host communities any form of ownership and control (Asuni, 2009). This kind of arrangement in the 1990s had left the people of Niger Delta abandoned, leaving the development of the region in the hands of strangers (the operating oil companies) at an era when Corporate Social Responsibility (CSR) was not part of their operation (Asuni, 2009). In this same period, a tribe (the Ogonis) in the Niger Delta was on the verge of extinction by the operations of SPDC on their land. Luckily, a bold knowledgeable leader (Ken Saro Wiwa) emerged among them to save his people from their certain doom (Bodo, 2019). The level of awareness of the local communities in the Niger Delta based on the benefits accruing from oil to the FGN and SPDC has necessitated several attempts of bribery of willing individuals from the region to sabotage the Ogoni struggle for fairness and justice (Bodo, 2018; Bodo,2019). In the 1990s, Ken SaroWiwa brought the plights of the Ogoni people to the knowledge of the world through Movement for the Survival of the Ogoni People (MOSOP) which adopted a non-violent approach using organised and civilised protests as well as persuasive appeals to the government and the international community (Bodo, 2018). Ken Saro Wiwa transcends the Niger Delta struggle to a level of knowledge and intellectual discussion. 
This involves creating awareness in the entire region of how blessed they were, what has gone out of their communities (profits in billions of US dollars), and the consequences (poverty and death) that were left behind (David \& Bodo, 2019; Bodo \& David, 2018; Bodo, 2019; Asuni, 2009; Saro-Wiwa, 1992, 1995). Through Ken, the perpetrators of environmental pollution were identified as the oil operating companies. He helped in funding MOSOP and in 1990 published the Ogoni Bill of Rights (Asuni, 2009; Bodo, 2019).

Ken Saro Wiwa attributed the injustice to the fact that the Ogonis were minorities and accused the majority groups of using their oil wealth to develop their areas at the expense of the areas that produce the oil (Osaghae, 1995). It has been reported that the cities of Lagos and Abuja were built with petrodollars from the Niger Delta (Bodo, 2019). The Ogoni demanded better treatment from the multinational oil companies as basic amenities were lacking in the region. Many believed that the Ogonis were too bold in their demands in 1990s, as some other ethnic groups in the region where suffering from worst conditions, but had giving up hopes of a better life and settled with their fate. In a message to the Ogonis, the then military administrator of Rivers State, Lieutenant Colonel D.M. Komo, made similar statement to validate this assertion when he said, "they don't have the monopoly of petroleum in Nigeria and cannot make demands that other (oil producing) communities are not making” (Osaghae, 1995). The Ogonis surprised even the military government with their demands, as no oil-producing community in Nigeria has gone to the extent of exerting the right to self- determination like the Ogonis did in the 1990s (Osaghae, 1995; Bodo, 2019).

With the demands for justice being turned down by the government and multinational oil companies, the Ogoni youths aggressively took matters into their hands by openly confronting the government forces and oil company operatives on their land. The government had always deployed the army, navy, and paramilitary police as a means of dealing with protests (Udosen et al., 2009). Consequently, it was reported that in order to shut down the Ogoni struggle in the 1990s, the government instigated violent conflicts between the Ogonis and the neighbouring Andoni communities between July and September, 1993. Furthermore, the Okrikas in Port Harcourt was also involved in the conflict in December that same year, where lives were lost and properties destroyed for no apparent reason (Osaghae, 1995). When the leaders from both sides met to resolve the crisis between them, they all agreed there was no issue that would have necessitated the clash in the first place, thereby giving the assumption of an external hand being responsible for the clash (the FGN and SPDC was 
suspected). The Ogoni militancy had reported that at various war fronts between the clashing communities, they met soldiers fighting with them with machine guns and AK47 riffles, as against their knives and cutlasses (Osaghae, 1995; Bodo,2019).

Moreover, there were reported cases of bribery from the FGN and SPDC, where some Ogonis who were later referred to as vultures were paid to bear false witness against Ken Saro Wiwa and the other MOSOP leaders (Bodo, 2019). In all cases of bribery, these Ogonis later came out, after they realised that Ken Saro Wiwa had been passed a death sentence because of their testimonies against him, to confess that they were giving monies by government representatives to give false statements in court. Soon after, the Ogoni struggle led to the dead of four prominent Ogoni leaders (Albert Badey, Theophilus Orage, Samuel Orage and Edward Kobani), Ken Saro Wiwa, and eight others. Furthermore, this resulted to the departure of SPDC in 1993 from Ogoniland (Bodo, 2019). In 1995, Ken Saro Wiwa was charged with incitement to murder and was executed by the Nigerian military government (Vaughan, 2011; Bodo, 2019). The Ogonis openly accused SPDC of orchestrating the murder of Ken and the eight other. Also, SPDC had also disregarded their involvement in the murder of Ken Saro Wiwa by stating that the allegations being made were false and were without merit (Bodo, 2019; SPDC, 2019). In 2009, SPDC agreed to pay $£ 9.6$ million to the affected families as an out of court settlement of a legal action which accused it of collaborating in the execution of Ken Saro Wiwa and the other Ogoni leaders (Vangham, 2011). The killing of Ken Saro Wiwa set the Niger Delta region into crisis, as direct attacks against the FGN and the multinational oil companies became common (Bodo, 2019). Today, the Ken Saro Wiwa-led uprising in the 1990s has given voices to other ethnic groups in the Niger Delta.

Ken Saro Wiwa brought the Ogoni Struggle and problems faced by the Niger Delta people to the knowledge of the entire world (Bodo, 2018; Bodo, 2019). The environmental awareness among other ethnic groups in the region has increased the demands for local ownership of lands and oil resources (Gimah \& Bodo, 2019a). The different ethnic groups started waging wars against the oil operators in their communities. It was reported that three successive major violent ethnic clashes erupted in the Warri area in 1997, 1999, and 2003 (Francis et al., 2011; Udosen et al., 2009). By December 1998, a youth conference was held in Kaiama which led to the Kaiama Declaration that crystallized into the Ijaw struggle for resource control (Francis et al., 2011; Udosen et al., 2009). In 2004, the situation in the region worsened as the Militant leader Dokubo Asari announces "Operation Locust Feast" and declares an "all-out-war" against the Nigerian State. Almost within this period, the violent conflicts in communities of 
Rivers, Bayelsa, and Delta states was on the increase to an estimate of about 150 per year, and over fifty armed groups with an estimated 20,000 to 25,000 armed youths were already operating in the region (UNDP, 2006; Francis et al., 2011; Udosen et al., 2009). Soon after, a booming business of Hostage-taking and oil bunkering became the order of the day, with attacks on oil facilities occurring on a daily basis (Bodo, 2019). Militant groups like the Movement for the Emancipation of the Niger Delta (MEND), headed by Tom Polo, the Niger Delta Vigilantes (NDV) by Ateke Tom, and the Niger Delta Strike Force (NDSF) headed by Farah Dagogo and many others began to emerge (Asuni,2009).

The militants expressed their intent for oil autonomy by loading a large number of boats and barges through illegal bunkering. The refined petroleum products and crude oil are transported through ships and barges and are sold in the high sea. The crude oil is sold at very low prices; when the price per barrel was 26 USD, as at 2003, it was sold for 7USD (Okumagba, 2009; Obi, 2009). By 2004, it was sold at about 15USD per barrel (Okumagba, 2009; Obi, 2009). The government inability to put an end to the activities of the militant groups has also contributed to the growing crisis in the region.

\section{The Outcome Of The Oil Crisis In The Niger Delta Region}

\section{Poor Standard Of Living}

Despite the enormous natural endowment and wealth that has been generated from the region, the Niger Delta settlement is always referred to as the poorest and least developed in Africa (Bodo, 2019). According Ken Saro Wiwa (1995), the Ogonis are hardworking and industrious people that engage in farming and fishing activities and had lived happily for many decades before the discovery of oil on their land. Despite that, they are impoverished because of the destruction of their livelihood. The Niger Delta environment has been described as a beautiful countryside that was a source of fresh air and green vegetation; but unfortunately, many years of oil exploration has made death and food scarcity the reality of the region (Bodo \& David, 2018). The rivers and lands have been massively polluted by the activities of the oil multinational companies for decades (David, Bodo \& Gimah, 2019). With the lands for agricultural cultivation and rivers for fishing activities, now contaminated by petroleum spills (that would take a minimum of 30 years to restore the ecosystem back to survivable or habitable level), the people are left with nothing to depend on (Bodo,2019).

The people of Niger Delta had surplus food for exportation in the pre-colonial and colonial eras, as theirs lands and rivers had always given them all they need to live as a prosperous people (Saro-Wiwa, 1995). 
Today, a region that has been described as been so blessed, now houses the poorest people in the country. These are people with no job or occupation because their primary occupation of fishing and farming has been taken away from them (David \& Bodo, 2019). Currently, in the region, food scarcity is a common occurrence with lack of social amenities such good roads, adequate hospitals, safe drinking water, electricity, schools, and markets (Bodo, 2019). The people now lived in polluted slums and squalors that is highly militarised to keep them dumb and voiceless as the government continue to explore the oil on their lands at the expense of the locals that is on the verge of extinction (Bodo, 2019; Darah, 2011).

\section{Youth Restiveness}

The definition of a youth could differ from one geographical area to another because it is determined by the society. A youth is always characterized by excessive energy that needs to be exerted which, if not guarded, could result into negative tendencies. They are described as being neither teenagers nor children (Ndu, 2000; Yusuf, 2001). Adewuyi (2008) saw youths as people between ages 15 to 24 years. In Nigeria, the National Youth Service Scheme (NYSC) regard young people as being within the age limit of 30 years. The N-Power programme of the Federal Government of Nigeria sees a youth as one that is within the age limit of 35 years (Igbo \& Ikpa, 2013). Realistically, in the Niger Delta and even in Nigeria at large, one is regarded as a youth as long as he or she is unmarried, and as an adult when married, irrespective of the age of that person.

Youth restiveness has been used as tool by the youth to get what they want from the relevant authority. The Niger Delta people have been reported to be once peaceful people that have been provoked severally and pushed to the wall beyond bearable limits. Thus, they only retaliate against their oppressors out of pains and to avert their death and extinction (Bodo, 2019). The consequences of several oil crisis and disagreement between the people and government had led to formation of several movements such as Movement for the Emancipation of the Niger Delta (MEND), Niger Delta People Volunteer Force (NDPFF), Niger Delta Avengers (NDA). There have also been multiplications of several countless cult groups that have laid claims of some abandon oil stations in the region (Bodo, 2019). Killings and burning of houses is now a daily occurrence in the region as attacks between the cults groups and the military has led many to desert their home towns to seek refuge elsewhere (Bodo, 2019; Bodo, 2018; Okolie-Osemene, 2015). 


\section{Politicizing of Environmental Issues}

The pollution of the Niger Delta region is no longer news, as the entire region suffers from air, water, and land pollution at a very high concentration (Onosode, 2003; NDES, 1997; Bodo, 2018; Famuyiwa, 1998; Eromosele, 1998; Orubu et al., 2004). The Nigerian government have also on several occasion recognised this fact and promised to addressed the challenges on the region with immediate effect (Bodo, 2019). Unfortunately, these statements by the government have been regarded as untrue and as a deceit by the government; a ploy that was used to calm down or delay the pressures from the people and neglect them in their sufferings (Bodo, 2018). Every election year, the proposed clean up of the region is usually the selling point on the lips of most politicians from the zone (their own representatives) and even those outside the zone (Bodo, 2018; Bodo, 2019). A typical example is the case of the Ogoni people where in 2011, the United Nation Environmental Programme (UNEP) recommended immediate remediation of the entire Ogoni ecosystem (a process that will take at least 30 years to restore the lost habitat) after thorough Environmental Impact Assessment of the land (UNEP, 2011). The same government that invited UNEP urgently to Ogoniland to assess the environmental conditions of the land have refused to implement the urgent recommendation for the immediate clean up of the land (Bodo \& Ukpong,2018).

\section{Unemployment and Crimes}

With the original source of livelihood of fishing and farming destroyed, the majority of the people in the region are unemployed and poor (Bodo \& David, 2018). The majority of the youths have embraced new trade of illegal bunkering, kidnapping, arm robbery, and prostitution (for the women) as a means of survival (Bodo, 2019). The unfortunate scenario in this entire eventuality is that the people involved in these businesses found it profiting than their former lost trade (Bodo, 2018; Bodo, 2019). It is believed that this new business could pay those involved hundreds of thousands naira weekly, making it impossible for them to quit the trade despite its hazardous nature (Bodo, 2018; Bodo, 2019; Gimah \& Bodo, 2019a). Oil business of illegal bunkering in the Niger Delta has further increased the destruction of the ecosystem in the region as the operators of this illegal oil business are not environmentally literate about their actions on their environment (Gimah \&Bodo, 2019b). Billions of naira has been reported to be realised from private individuals, operating companies, and state governments in the region on ransom payments on kidnapped victims to militants groups (Okolie-Osemene, 2015; Bodo, 2019). Unfortunately, the military that were sent to checkmate these criminal vices are fully 
involved with the locals in sharing the loots from these businesses (Bodo,2019).

\section{Bribery and Corruption}

It is believed that the cleanup of Ogoniland is being stalled by bribery and corruption, as the leadership of the Movement for the Survival of the Ogoni People (MOSOP) has been reported to have been divided over their involvement in the exercise (Bodo, 2019). SPDC has been severally accused by the Ogoni people for dividing the people and initiating crisis among themselves by bribing some of the corrupt locals (Bodo, 2018). In 1995, during the Ogoni uprising, SPDC was accused of bribing the four Ogoni leaders that was later killed by mob action and for collaborating with military government in the killing of Ken Saro Wiwa and eight others (Bodo, 2019). It has been reported that the revenues (13\% oil derivation) from the Federal Government to the states and the parastatals (Niger Delta Development Commission, Ministry of the Niger Delta, etc.) in the region running into billions of naira for over the years has been mismanaged by their leaders (Bodo \& David, 2018; Bodo, 2018). Many have also ascribed the backwardness of the Niger Delta region to the corruptness of their leaders (Bodo, 2019).

\section{Conclusion}

Oil crisis in the Niger Delta is saddled and fuelled by negligence, failed promises, and corruption in the part of the government and the operating oil companies to the people of the Niger Delta. Delays in meeting the basic needs and demands of the people have resulted in a state of anarchy and more devastation of the ecosystem. The revenue that accrues to the state has been reduced over time due to the activities of illegal oil bunkering, pipeline vandalism, and diversion of petroleum products by oil thieves. Several injustices done to the people such as the persistence killings and militarisation of region, refusal to implement UNEP recommendations in Ogoniland, and the lack of human and social empowerment has aggravated the crisis on a daily basis. The people now show their grievances and displeasures of being marginalised through attacks on oil workers, military personnel, and oilfacilities.

The government should ensure peace in the Niger Delta region by showing true concern to the plight of the people through action-oriented plans to meet their basic needs. The cleanup of Ogoni, as recommended by UNEP in 2011, and the employment of thousands of youths whose livelihood has been lost due to oil exploration on their land will be a starting point. Furthermore, the government must earn the trust of the people by being truthful in their promises to them. Also, the government 
should avoid making common and politicising environmental issues that borders on human life and the survival of the Niger Delta ecosystem. Environmental protection and literacy should start from the Nigerian government and then be inculcated into the people of the Niger Delta. The environmental consciousness of citizen is the beginning of sustainable development.

\section{References:}

1. Adewuyi, T.D.O. (2008). Utilization of self counselling theories for youth peer relationship.The Lagos

2. Adomokai, R., \&W. R. Sheate (2004). "Community participation and environmental decision-making in the Niger Delta," Environmental Impact Assessment Review, 24 (5).495-518.

3. Aghalino, S. O. (2011). Oil and Cultural Crisis: The Case of the Niger Delta, Nigeria.Africana: The Niger Delta 5 (1). 1-21.

4. Aghalino, S.O. (2001). - On the Social Consequences of Oil and Gas Exploration and Production in the Niger Deltall, in International Journal of Economic and Development Issues, 1(1)196-206.

5. Aghedo, I. (2011). Conflict Management and Peace-building: In Iyamu, E.O.S and Salami,L.I. (eds) Peace Studies and Resolution. Benin City: the Guide press.

6. Akinbi, J.O. (2012). The Niger Delta Environmental Crisis in Nigeria: A Perspective Analysis.African Research Review. 6(3):150164.

7. Akinola, O.O. (2008). - The Nature of Government Involvement in the Niger Delta Conflicts: Implications for Nation Building\|, In Babatolu, J.S. and Ikuejube, G. (eds.), Perspectives on Contemporary Socio-Political and Environmental Issues in Nigeria, (Ibadan, Alafas Nig. Company),10-19.

8. Akpan, P.U. (2014). Oil Exploration and Security Challenges in the Niger-Delta Region: A Case Of Akwa Ibom State, Nigeria. IOSR Journal of Research \& Method in Education (IOSR-JRME), $4(2): 41-48$.

9. Aniefiok, E., Udo, J., Margaret, U., \& Sunday, W. (2013). Petroleum Exploration and Production: Past and Present Environmental Issues in the Nigeria's Niger Delta. American Journal of Environmental Protection, 1(4):78-90.

10. Asuni, J.B. (2009). Understanding the armed groups of the Niger Delta. Council on Foreign Relations Working Paper.

11. Badmus, I.A. (2010). Oiling the Guns and Gunning for Oil: Oil Violence, Arms Proliferation and the Destruction of Nigeria's 
Niger-Delta. Journal of Alternative Perspectives in the Social Sciences. 2(1):323- 363.

12. Bodo, T. \& David, LK. (2018). The petroleum exploitation and pollution in Ogoni, Rivers State, Nigeria: The community perspective. European Scientific Journal. 14(32): 197- 212.

13. Bodo, T. \& Ukpong, IE. (2018). Community Participation in the Remediation of Petroleum Impacted Sites in Ogoni, Rivers State, Nigeria. Multi-disciplinary Journal of Research and Development Perspectives 7:97-104.

14. Bodo, T. (2018). Community understanding of the environmental and socio-economic consequences of Petroleum Exploitation in Ogoni, Rivers State. International Journal of Advanced Research and Publications. 2(11):51-55.

15. Bodo, T. (2019). Deep Issues behind the Crisis in the Niger Delta Region: The Case of Oil Exploration in Ogoniland, Rivers State, Nigeria. Asian Journal of Geographical Research, 2(1):1-12.

16. Collins, E. (2018).Oil Exploration in the Niger Delta: Its' Gains and Loss. International Journal of Geography and Environmental Management. 4(3): 24-31

17. Darah, G.G. (2001). "The Socio Economic and Political Challenges of the Niger Delta" In: Ozo-Eson PI and Ukiwo U (eds.) Challenges of the Niger Delta. Port Harcourt: CASS pp.19-36.

18. David, LK., Bodo, T., \& Gimah, BG. (2019). Petroleum pollution and decrease neuroplasticity in brain development of the Ogoni children in Rivers State, Nigeria. Journal of Advances in Medicine and Medical Research 29: 1-13.

19. Doyle, A.B., Pappworth, S.S.R., \& Caudle, D.D. (2008). "Drilling and Production Discharges in the Marine Environment," Environmental Technology in the Oil Industry, S. Orszulik, ed., pp. 155-187: Springer Netherlands.

20. Ebeku Kaniye, S.A. (2001). "Oil and the Niger Delta People: The Injustice of the Land Use Act." Centre for Energy, Petroleum and Mineral Law and Policy (9) Article 14. http://www.dundee.ac.uk/cepmlp/journal/html/vol9/article914.html.

21. Ejovi, A., Ebie, S. \& Akpokighe, O. R. (2014). Globalization and Environmental Degradation of the Niger Delta Region of Nigeria, Research on Humanities and Social Sciences .4(13),142-152.

22. Eromosele, V.E. (1998). Costing Niger Delta's oil spills: A joint stakeholder's approach. 9th International Conference on the Petroleum Industry and the Nigerian Environment, Abuja, November, 358-368.

23. Fagbadebo, M.O. \& Akinola, O.A. (2010). Post-Amnesty Niger 
Delta and the Promise of Development: Issues, Prospects and Problems, From the Selected Works of Omololu Michael Fagbadebo, Available at: http://works.bepress.com/otomololu/2.

24. Francis, P., Lapin, D. \& Rossiasco, P. (2011). Securing Development and Peace in the Niger Delta: A Social and Conflict Analysis for Change. Woodrow Wilson International Center for Scholars Africa Program, Washington, DC.

25. Frederick, O.O., Asmuni, A., Idris, K. \& Othman, J. (2013). The causes, effects and Potential Solution to the Deep Rooted Niger Delta Oil Crisis. International Journal of Social and Behavioural Sciences 1 (6): 122-129.

26. Genova, A.W. (2007). Oil and Nationalism in Nigeria, 1970-1980, Ann Arbor, MI: UMI

27. Gimah, B.G. \& Bodo, T. (2019a). Creation of Awareness through Environmental Adult Education as a solution to the Problem of Habitat Loss in Ogoni, Rivers State, Nigeria. International Journal of Advanced Research and Publications. 3(1):22-28.

28. Gimah, G.B. \& Bodo, T. (2019b). Curbing Human Activities That Degrade the Environment: The Relevance of Environmental Adult Education. Earth \& Environmental Science Research \& Reviews. 2(5): 1-7.

29. Ibaba, I.S. (2009). Violent Conflicts and Sustainable Development in Bayelsa State. Review of African Political Economy 36 (122): 555-573.

30. Ibori, J.O. (2009). - Economic development, Niger Delta and the future of Nigeria.l The Guardian, October 23, 2009. http://www.ngrguardiannews.com

31. ICG (2006). The Swamps of Insurgency: Nigeria's Delta Unrest Brussels. ICG Report 115.

32. Igbo, H.I. \& Ikpa, I. (2013). Causes, Effects and Ways of Curbing Youth Restiveness in Nigeria: Implications for counselling. Journal of Education and Practice. 4(6): 131- 137.

33. Ikelegbe, A. (2006). - The Economy of Conflict in the oil rich Niger Delta Region of Nigeria, Journal of Asian and African Studies,5(1):1-7.

34. Nannen, B. (1995). - Oil Producing Minorities and the Structure of the Nigerian Federation: The Case of Ogoni Peoplell, Journal of Commonwealth and Comparative Politics, (33), Nigerian Tribune, July 23, 1998.

35. Ndu, A. (2000). The role of family in managing indiscipline among youths in Nigeria.Journal of Counselling Psychology. 1, 45 - 51. 
36. Niger Delta Environmental Survey (NDES) (1997). Environment and Socio-economic Characteristics. Phase 1 Report, Port Harcourt.

37. Nwoba, M.O. E. \& Abah, E.O. (2017). Impact of Crude Oil Revenue (COR) on Economic Growth in Nigeria (1960-2010). IOSR Journal of Humanities and Social Science. 22(7): 85-99.

38. Obaje, N.G. (2009). Geology and mineral resources of Nigeria, Berlin; London: Springer.

39. Obi, C. (2009). Nigeria's Niger Delta: Understanding the Complex Drivers of Violent-Oil Related Conflict. African Development, 35, (2):103-128

40. Odalonu, B.H. \& Eronmhonsele, W. (2015). The irony of amnesty programme: incessant oil theft and illegal bunkering in the Niger Delta region of Nigeria. International Journal of Humanities and Social Science Invention. 4(8): 09-18.

41. Ogbeifun, B. (2014). Why Nigeria should not treat oil theft with kid gloves-Ogbeifun. Vanguard in Sweet Crude, January 7. Retrieved on Julne 29, 2019 fromhttp://www.vanguardngr.com/2014/01/nigeria- treat-oil-theftkid-gloves-odbeifun/

42. Ogbonna, G.N. \& Appah, E. (2012). Petroleum Income and Nigerian Economy: Empirical Evidence.Arabian Journal Of Business And Management Review,9(1):33-59.

43. Okolie-Osemene, J. (2015). Oil Companies and Lethal Violence In Nigeria: Patterns, Mapping and Evolution (2006 - 2014). IfraNigeria Working Papers Series, N44.

44. Okumagba, P. (2009). Ethnic Militias and Criminality in the NigerDelta. African Research Review, 3(3): 315-330.

45. Onosode, G. (2003). Environmental Issues and the Challenges of the Niger Delta: Perspectives for the Niger Delta Environmental Survey Process. CIBN Press.

46. Orubu, C.O., Ayodele O. \& William, E. (2004). "The Nigerian Oil Industry: Environmental Diseconomies, Management Strategies and the Need for Community Involvement. Journal of Human Ecology 16(3): 203-214.

47. Osaghae, E.E. (1995). "The Ogoni Uprising: Oil Politics, Minority Agitation and the Future of the Nigerian State", African Affairs, Nos. 94, pp.325.

48. Pearson, S.R. (1970). Petroleum and the Nigerian Economy: Stanford University Press

49. Rafiu, J. (2008). - Language, Diplomacy and Conflict Resolution on the Niger Delta Crisis in Nigeriall, in Babatolu J.S. and Ikuejube, G. (eds.) Perspectives on Contemporary Socio-Political and 
Environmental Issues in Nigeria, (Ibadan, Alafas Nig. Company),20-32.

50. Saro-Wiwa, K. (1992). Genocide in Nigeria. The Ogoni Tragedy. London Lagos and Port Harcourt. Saros International Publishers.

51. Saro-Wiwa, K. (1995). A Month and a Day; A Detention Diary. London Penguins

52. SPDC (2019).

Economic contribution. https://www.shell.com.ng/media/nigeria-reports-and-publicationsbriefing-notes/economic-contricution.html (Retrieved 2nd January, 2019).

53. Udosen, C., Etok, A. \& George, I.N. (2009). Fifty Years Of Oil Exploration In Nigeria: The Paradox Of Plenty. Global Journal of Social Sciences, 8(2): 37-47

54. UNDP (2006). Niger Delta Human Development Report. Vanguard (2002), '2,483 Lives Lost in Odi Armed Invasion', Vanguard, 20November 2002,http:// www.allafrica.com (Retrieved $2^{\text {nd }}$ January, 2019).

55. UNEP (2011). Environmental Assessment of Ogoniland, Nairobi, Kenya: United Nations Environment Programme.

56. Vangham, A. (2011). Oil in Nigeria: a history of spills, fines and fight for right for rights. The Guardian, Thursday $4^{\text {th }}$ August,2011.https://www,google.com/amp/s/amp.thegu ardian.com/environment/2011Aug/04/oil-spills-fines-fines-fight (Retrieved 2nd January, 2019).

57. Vassiliou, S. (2009). The A to Z of the Petroleum Industry: ScarecrowPress.

58. World Bank (2000). Environmental Economic Study of the Niger Delta: Report on Niger Delta. Uyo: Golden Education Publisher.

59. Yusuf, S.A. (2001). Youths and national orientation. In A.A. Adegoke (Ed.) proceeding of the 25th National Conference of the Counselling Association of Nigeria $11-15$. 